\title{
Use of social media in Election Marketing in Bangladesh: Its impact on Voting Behavior \\ ${ }^{1}$ Bidyut Kumer Balo and ${ }^{2}$ Niaz Mahmud Shawon
}

\begin{abstract}
Purpose: The main purpose of the study is to illustrate the use of social media in election marketing in Bangladesh and to identify how social media is changing voting behavior of voters. Social media marketing involves the use of online social media tools-such as Facebook, Twitter, Instagram and LinkedIn - to reach voters in innovative ways. In previous years, traditional media play a significant role in creating awareness among people, but over a period of time social media becomes an important marketing tool which not only aware people but also help to attract them in election marketing

Methodology: The researchers use 'Quant-Qual design' for this research. Related articles, books etc. are reviewed for gathering secondary data. Convenience sampling method has been used to collect primary data from 120 registered voters.

Findings: The study has found that social media efficacy within voters create voting awareness and political knowledge and change their mentality towards politics and make them aware about their voting right. The best summary of this research is that social media build a relationship between politicians and people through online campaign that helps to generate public trust for the politicians.

Research Limitations: The main limitation of this study is that some of the people are not comfortable to give their comments on this survey because of the political content. It limits the validity of the research.

Practical Implications: Study will help both voters and politicians in national election as well as all types of election taking place in any organization like schools, colleges, banks, universities in Bangladesh and all over the world.

Originality: The study cites the present situation of using social media in election marketing in Bangladesh. Study also provides guidelines about the future effectiveness of the social media in Bangladeshi election and its impact on voting behavior.
\end{abstract}

Key word: Social Media, Voters, Election Marketing, Voting Behavior.

\section{Introduction}

The worldwide arrangement of organized PCs, servers and switches known as the Internet has changed numerous parts of present-day society and social association. The online appropriation of products and ventures, for example, has impacted practically every industry and has drastically changed numerous. Close by trade arranged mechanical improvement has been an ascent in what has been named "Social media." One of the most noteworthy advancements associated with Social media is the rise of social network sites (SNSs), for example, Facebook, LinkedIn, Instagram, Twitter, and Google Plus. Social media gives the advantage of being momentary, exact and target particular. Online networking has picked up fame worldwide as of late, in any case, the idea is not new. Amid the mid-90's with far reaching adjustment of PCs clients were additionally pulled into administrations like chat rooms, newsgroups and texts (Lengel et al., 2004). In late 2006 when Twitter was propelled, its makers expressed that the reason for "tweets" was to tell your supporters what you were doing (Jackson and Lilleker, 2011). Be that as it may, Social media in the second decade of the 21 st century is utilized not only for paltriness, but rather for genuine social and political informing, and offering suggestions to take action that have stirred both protest and revolution.

"Technology and social media have brought power back to the people."

Mark McKinnon, American Political Advisor Social networks have been particularly popular. A Techno graphic survey (Bernoff and Li, 2008) found that one in four online American adults visited social networking sites at least monthly.

\footnotetext{
${ }^{1}$ Assistant Professor, Department of Marketing, Faculty of Business Studies, Jagannath University, Dhaka-1100, Bangladesh

E-mail: bidyutkumerbalo@gmail.com

${ }^{2}$ MBA Student, Department of Marketing, Faculty of Business Studies, Jagannath University, Dhaka-1100, Bangladesh

E-mail: niazmahmudshawon@gmail.com
} 
Business Review- A Journal of Business Administration Discipline, Khulna University, Volume: 13, Number: 1E2, January-December 2018, pp.01-12 (Print ISSN : 1811-3788; Online ISSN : 2664-3502)

\section{Rationale of the Study}

Considering (Fisher, 2007) recommendations that the researcher should choose a topic that interests them and even possibly excites them and the chosen topic should also arise some interest to some external audiences. Social media is quickly getting to be distinctly a standout amongst the most broadly utilized types of correspondence. Customers of different kinds are as often as possible utilizing social media to train themselves about items and administrations, arrange, discover sellers and post employments. Social media has radically changed the way individuals speak with each other and share data. The author has picked this subject, as a matter of first importance, out of individual interest. It additionally seemed fascinating, as it is a popular theme, and continually advancing and turning out to be increasingly critical. Social media and digital marketing are such an immense matter; it is difficult to give a general review appropriate to any sort of business. That is the reason, with a specific end goal to get significant outcomes; the author has chosen to center his research around social media in politics. Once more, principally out of individual interest. Social media is now playing a new significant role in Bangladesh democracy as well. A Research done by Bangladesh Telecommunication Regulatory Commission (BTRC) in 2016 highlights that 80 percent of all active Internet users in Bangladesh use social media. According to the report, 85 percent of the users use mobile for social media.

\section{Literature Review}

This chapter critically includes available literature in and around this research topic along with various studies that are relevant to this topic. Social media have played a big role in different aspects of our daily life and its influence is very crucial now a day in marketing including election marketing. Few researchers have already published several research articles on the effect of social media on election marketing; however, the topic yet not focused on the election marketing in the context of a developing country like Bangladesh. A common finding from the previous research on the effect of social media on election marketing is that all the politicians try to use social media in order to influence the election and social media is an integral part of election marketing.

Social Media: The internet was first introduced in January 1, 1983. Internet plays a vital role in all spheres of the world culture, activity, and development. The influence of the internet has become gigantic with the introduction of social media. The first social media called "Six Degrees" was introduced in 1997. After that social media, many social media were introduced like Facebook, twitter, Instagram etc. Nowadays social media influence our daily activities and increase the use of internet to us. Many Authors define social media in their own opinion. According to (Gould, 2015) "Social media are web based tools for interaction that, in addition to conversation allow users to share content such as photos, videos and links to resources. Social media are the networking sites, which are internet-based applications that allow the users to create a public profile within the secure and closed system, have a list of users whom they have a relationship with and are able to view their own friends list and that of others within the system (Ellison, 2007). At the end of the definition, social media is a system to communicate with other people through word of mouth powered by technology.

Social Media Effectiveness : "The best benefit of a social media program is gaining an understanding of what people are saying about your brand, product or service(listening); analyzing what you find to extract meaning(social media analytics) that is relevant to your work; and then developing a response program(active listening) (Evans, 2010)." "Every interpersonal organization is an interchanges channel that can contact distinctive groups of onlookers with changed needs and wants (Ramos, 2015)." Indeed, the social web has opened an exceptional opportunity for to advertise for a fraction of what big-budget advertising costs. But even though social media is very cost-effective, it is becoming imperative to allocate a budget for social media advertising, especially since Facebook declared that the organic (unpaid) reach is falling short. There is indeed a clear decline in the number of people, businesses reach with their posts. Now Facebook is advising marketers to pay for getting more rich, as (Delo, 2013) explains "marketers are told they should consider paying a distribution "to maximize delivery of your message in the news feed." In order to understand the effectiveness of social media, everyone must see the use of social media. Every organization, political party, business person, politicians and scholar use social media to share their information and gain knowledge of social media. This analysis gives you the data that how much important social media for us. "Be on top of what's working in your social media and online marketing efforts so you can continue doing the same, or make adjustments to get better results (Bendror, 2014)." 
Business Review- A Journal of Business Administration Discipline, Khulna University, Volume: 13, Number: 1E2, January-December 2018, pp.01-12 (Print ISSN : 1811-3788; Online ISSN : 2664-3502)

Bangladesh Scenario on Social Media: Bangladesh's large and increasing population along with the increasing mobile density, especially in urban areas in Bangladesh, has stirred a remarkable growth in the number of people online. Moreover, as the middle class in the country expands, more and more Bengalis are expected to get online. The number of social media users is also increasing. However, the traditional media is still significant in Bangladesh. Bangladeshi metro cities are the centers for the digital outburst, but the effects are yet to reach the more rural parts of the country. The social media are not just limited to these broad categories. Any website that invites individuals to interact with it and network with other existing or new users comes under the definition of social media. These sites unlike all other sites have it own importance and use. The use of social media for political agendas in Bangladesh is a new concept. However, the rise in the use of social media in political campaigns in Bangladesh cannot be overlooked now. Bangladesh's main political parties - "The Bangladesh Awami League" and 'The Bangladesh Nationalist Party (BNP)' are tapping into the social media platforms like Facebook and Twitter. They are doing so to out-innovate each other. There are two main important drivers that have led to the adaptation of social media by political parties in Bangladesh. Firstly, to connect with a large number of potential voters who generally are hard to meet face to face and furthermore, to take advantage of 90+ million Facebook clients who are required to impact decision results in the year 2019. This year alone, there are over 1 million first time registered voters in the country (Prothom Alo Report, May 13, 2018).

Importance of Social Media in Bangladesh Politics: For politicians, the coming parliamentary_decision is not about getting chosen; it is about getting socially chosen. Social media has changed the way individuals think, compose and respond; however, political savants trust it has additionally impacted the way individuals vote. The greater part of the political gatherings knows about the beat and the drive of people in general via social media timelines, which is the reason increasingly politicians understanding the significance of social media as an electoral tool. Be that as it may, do social media truly connect the gap amongst candidates and voters? Does digital democracy have the ability to change political fortunes? What makes for a triumphant political system and exactly how is social media in charge of a social beat in our nation? Along these lines, the investigation and translation of the above questions will be completed by this examination, by leading surveys among more youthful voters. This decision will be a litmus test to put the focus on the question we began with; can social media impact these voters? The appropriate response may not be an unequivocal yes, but rather it absolutely isn't a no. It's an answer in advance. The relationship between social media and politics is pulling in the craving for change. But the usage limit of social media is restricted to urban areas only. A person belonging to rural areas is still very far from usage of social media. Since innovation had not infiltrated into rural parts. In this way, the politicians will be unable to associate or contact rural individuals by social media. So, here again traditional media play a significant role in influencing them. Social media connects people and gets them talking and sharing is one thing. Be that as it may, it's turned out to be more important when it permits campaigner to know the voters, focus on a particular group of audience, splice demographics, mobiles support, and urge individuals to participate. More and younger Bangladeshis are getting on the social media bandwagon, and this will increase with time, according to Bangladesh Telecommunication Regulatory Commission (BTRC) and IMRB International, the number of Internet users in Bangladesh had reached 73.965 million in October, 2018 and by August 2019, Bangladesh will have 90.000 million internet users, at which point of time, it is expected to be the largest Internet base in the developing world. These social networking sites are acting as a great medium for view mobilization. People are feeling free in sharing their thoughts on any issue and even youth is raising their voice against social acts like an infringement of Human Rights, defilement, and so on. With political discussions occurring at these sites, a relevant question is arising: could activity on sites like Twitter be a predictor of election results? (Tumasjan et al., 2011) discovered that the relative volume of tweets closely mirrored the results of the German federal elections. The study found that youngsters tend to get political information from social media more than whatever other age group. Politicians, citizens and journalists increasingly adopt new social media like Twitter, Facebook and YouTube to support their political purposes, be it to engage with other stakeholders in the political public sphere, campaign, disseminate or retrieve information, or contribute to rational-critical debate (Sauter and Bruns, 2013). An overview of the Bangladeshi social media, literature suggests that there has been very little research on the impact of the social media on political campaign in general and voting behavior in particular. Therefore, in this article researchers try to study the impact of the social media on political campaigns in Bangladesh with a special emphasis on voting behavior among Bangladeshi youth. 
Business Review- A Journal of Business Administration Discipline, Khulna University, Volume: 13, Number: 1E2, January-December 2018, pp.01-12 (Print ISSN : 1811-3788; Online ISSN : 2664-3502)

Social Media Effect on the Political Environment Changes: The restructuring of social media's interpersonal communications is revamping the political environment. The major change is an increase in public participation. Secondly, the communications between the government and public have changed to direct contact from indirect communication. The pace at which public opinion develops today is faster than that in the past. Instead of depending on the mass media, the citizens can directly express views and opinions to the politicians on Facebook or Twitter. Social media have paved the way for citizens as being journalists and made it challenging for the officials to control the information. For instance, Twitter first posted the news of the death of Osama bin Laden even before the US government openly confirmed it. The political leaders are now aware of the fact that they will be increasingly judged by the information they provide on social media networks to the public. Moreover, it also not shocking in today's scenario, that's citizens are more likely to vote for leaders who are part of or member of their own views and beliefs. Bangladesh has been one of the most forward-thinking countries in relation to its resources in the past 10 years and this show, as in the last election social media was not really evident in the country at all. In any case, today the Facebook has 55 million users account set up in the nation, which recommends that the Bangladeshi people regard social media as enormously imperative to the way they advance as a broader and wider society. (Huang et al., 2014)

Social Media Effect on Electoral Participation: Participation effects refer to those ways, which generally convince individuals to participate in a political campaigning and the voting process. As per Claassen (2007), a model, citizens participate in a political process when their vicinity calculations display a non-zero policy stake in the election outcome. In other words, if an individual realizes his personal beliefs are not being challenged by either of the candidates in the election, they will not participate. However, if individual realizes a leader challenges his personal beliefs, they will be willing to participate in the election. (Claassen, 2007). Claassen (2007) eventually established that extreme policy motivated individuals participated in the political process because of their extreme views regardless of the election, whereas vicinity motivated individuals only participated when they had an alleged stake in the outcome of the election. In addition, American natives keep on demonstrating expanding enthusiasm for different political exchanges and growing their discoursed to person to person communication locales and different other Internet news and communicate destinations, there keeps on being a decrease in voter turnout of US presidential decisions. Various variables are being studied to find out the reasons for this participation effect.

Influence of Social Media on Voter's Choice: These choices refer to those ways, which generally persuade an individual to cast a ballot in favor of any particular political leader. The voters relate their own views on issues to those of each of the parties and support those parties whose positions are most similar to or generally in the same direction as their own opinions. When an individual voter has made his decision of casting a ballot of his own will, another important decision-making process takes place inside his/her head - what candidate or political party to vote for? In this decision-making process, information exchange plays a vital role. In this situation two encouragements can be identified - first is obviously the information exchange process related to the party or candidate to choose and second is more related to the decision-making process inside a person's head. Sabato (1984) has reported that, during an election, each and every individual voter has five primary choices. First is voting in favor of either party's candidate. The Second choice is voting against either the party nominees. Finally, not voting at all for any political candidate (McCarron et al., 1984). Essentially, high turnout levels are not the sole realistic facts that theories of voter turnout should address. Without being comprehensive (Geys, 2006) mentioned several other reasons effecting voter choice. Firstly, main elections tend to attract more voters than secondary parliament elections. Secondly, some people have a greater prospect of showing up at the voting polls. This holds true for richer or more educated individuals and women. Younger voters, as well as the elderly are less expected to cast a vote. Thirdly, people try to refrain to a large extent because they are feeling separated, that is, they feel that no party represents their ideas and beliefs. Fourthly, voters are more likely to show up under comparative election systems and when the political candidates are in a highly competitive race. And lastly, voters fail to cast vote for their true favorites in order to cast insincere or strategic ballot.

Impact of Social Media on Young Voters: "Envision an era of children who can live easily in more than one world, in more than one culture, with more than one language" (Nasseri et al., 2003)" The expression "Era Y" was initially begat in the USA and it is utilized to characterize the youngsters of today (conceived in the later piece of the century). Scholars do not agree on a universal characterization of Generation Y (also referred to as Millennials): if 
Business Review- A Journal of Business Administration Discipline, Khulna University, Volume: 13, Number: 1E2, January-December 2018, pp.01-12 (Print ISSN : 1811-3788; Online ISSN : 2664-3502)

on one hand, optimists claim that the young people of today will change the world for the better, on the other hand, pessimists question the capacity of this generation to become responsible adults. However, there are a few characteristics that shape the Generation $Y^{\text {ec }}$ s profile: they are digital natives (Tapscott, 2009), wired (Thompson et al., 2003), and technologically savvy. They are also criticized for their individual approach and egoistic personalities, mainly due to the fact that they believe that other people's opinions are rarely important. But what are Millennials" attitudes towards political participation? According to Bennett (1998), the ideal citizen is informed about issues of public concern, active in community and political groups, and enthusiastic to participate in political actions, such as voting or campaigning (Bennett, 1998) ; (Zukin et al., 2006). In addition, a study of young people's electoral participation in Europe, conducted by Fieldhouse et al., (2007) also found that young people have lower rates of voting than their elders. They have very low levels of political interest and knowledge, they do not trust politicians, and they do not believe they have the power to change anything. However, there are also arguments claiming that young people are not characterized by a "lack of pathos" (Coleman and Rowe, 2005) concerning main issues and values. Coleman (2005) claims that, instead, they show interest in new forms of participation, such as signing petitions or demonstrations, reshaping the political landscape. Furthermore, he states that it is not the young people who are disengaged from formal politics, but the political institutions are disconnected from young people (Coleman and Rowe, 2005). (Bennett and Iyengar, 2008) supports (Coleman's, 2005) idea that young people are more inclined towards nontraditional forms of political activities. In addition, he reasons that the young generation is disengaged from traditional politics because they do not understand politicians. For youthful voters, interpersonal availability has become an essential component of every aspect of their lives from consumption to education to civic engagement (Loader and Mercea, 2012). Ward, (2012) found that young people, in the habit of using social networking sites, prefer co-productive interactivity and socialization in order to participate politically. Because social media usage is highest in the youngest voter demographic, political campaigns must use this communication tool to engage this sector of the voting population. Gerodimos, (2012) found that the appearance of information is another important element is determining young people's motivation to engage. The study found that youth are less likely to engage in public debate or discussion about politics because they are not as knowledgeable and are more self-conscious about discussing politics among people whom they consider older and wiser (Gerodimos, 2012). Research also suggests that the constant flow of information showing up on Facebook and Twitter feeds, search engine advertisements and email is so overwhelming that many young people ignore it all together.

Social Media Effect on Voter Engagement: Also, one of the struggles in encouraging online contributors in a political forum and various discussions to vote are keeping them engaged over the time period. The bond between a registered voter and the political parties is one of the most important features of modern democracy; influencing voters and how they interpret politics, reaching decisions, assessing the government performance and finally how they participate in the political process. According to Dale and Strauss, (2009), for some elections if it is ensured that voters are paying attention to the messages that will persuade them to vote, the turnout strategy will prove to be successful. Most of the Bangladeshi political contenders are using the social media to create awareness, however, there still are many of them who are still pursuing traditional media for campaigning. According to Gulati and Williams, (2011) - education, income, culture, age and urbanization are all possible influences on a candidate's Internet use. Around, one in three young voters under the age of thirty-six rely on the Internet as their primary source of attaining political information (Panagopoulos, 2010). However, Kushin and Yamamoto, (2010) suggested that the growing online political behavior has been relatively accelerated by the latest emergence of new interactive and media rich websites.

Social Media Impact on Political Candidate: The effect of social media on the political candidate estimate has become an increasingly important issue as the Internet has become an extensively used communication medium throughout the world. According to Tolbert and McNeal, (2003), suggested that the internet become more widely used information tool for gathering political candidate information, therefore voters are more likely to be properly informed and later participate in the political process. To sum it all up, according to them, the Internet can become the medium to fill the void, which television and broadcast news could not.During the 2008 US presidential elections, social media proved to be an effective medium for a presidential candidate to distribute information. Kushin and Yamamoto, (2010), tried to establish if social media had an impact on actual on political self-efficacy 
Business Review- A Journal of Business Administration Discipline, Khulna University, Volume: 13, Number: 1E2, January-December 2018, pp.01-12 (Print ISSN : 1811-3788; Online ISSN : 2664-3502)

and involvement. They also established that from 1996 to 2008 year, the percentage of Americans who got political information online increased from $4 \%$ to $40 \%$ (Rainie and Horrigan, 2007);(Rainie and Smith, 2008). The dependence on Internet information for politics has been more popular among the younger generations. In a political campaign, social media platforms like Facebook, provided voters to become more politically engaged with candidates.

\section{Objectives of the Study}

The objective of this study is to examine the voters about social media effectiveness on voting decision and to analyze the use of social media in Bangladeshi election marketing.

Specific Objectives of the study are as follows:

- To identify the role of social media in politics.

- To find out the development of the relationship between voters and politicians through social media.

- To demonstrate the impact of social media on voters and the importance of social media to politicians.

- To demonstrate how social media is important for politicians to reach to their voters.

- To identify that how social media creates an open discussion about politics and election between electorate and voters.

- To explore the activeness of the voters in social media.

- $\quad$ To identify the effect of social media on young voters.

\section{Methodology of the Study}

This research is a descriptive research which is prepared on the basis of primary data and secondary data. The sources of these primary data are field survey. The sources of secondary data are articles, magazines, journals and newspapers etc. This study has used convenience sampling method for collecting data from the users of Social media and politicians. Questionnaire survey method is followed and both five points Likert scale \& Rank order scale are used in the Questionnaire. All the registered voters above the age of 18 Years make to be the population for the purpose of this research. Sample size is 120 social media users as well as registered voters and politicians from Dhaka city and Jessore city. The study covers 120 social media users of Dhaka city and Jessore City. SPSS software is used for data analysis.

\section{Findings and Analysis of the Study}

Table 1: Demographics of the Respondents

\begin{tabular}{|c|c|}
\hline Demographics & Study $(\mathrm{n}=120)$ \\
Frequency (\%)
\end{tabular}


Business Review- A Journal of Business Administration Discipline, Khulna University, Volume: 13, Number: 1E2, January-December 2018, pp.01-12 (Print ISSN : 1811-3788; Online ISSN : 2664-3502)

\begin{tabular}{|c|c|}
\hline Respondents Age & \\
$18-24$ & $73(60.8 \%)$ \\
$25-35$ & $32(26.7 \%)$ \\
$36-46$ & $10(8.3 \%)$ \\
$47-60$ & $4(3.3 \%)$ \\
$61 \&$ Above & $1(.8 \%)$ \\
\hline
\end{tabular}

Source: Computed Primary Data Using SPSS 22 Version

Interpretation: Study ensures participation respondents of various genders, marital status, education level, various occupations and respondent's age.

Table 2: Descriptive Statistics of Respondent's Active Time and Usage Rate of Social Media

\begin{tabular}{|c|c|}
\hline \multicolumn{2}{|c|}{ Descriptive Statistics } \\
\hline Respondent's active time on Social Media & Mean \\
Facebook & 5.95 \\
Twitter & 1.87 \\
Instagram & 3.44 \\
LinkedIn & 2.27 \\
Google+ & 4.31 \\
Other social media like Imo, WeChat etc. & 3.16 \\
\hline Frequency of usage of social media & 3.81 \\
Facebook & 0.45 \\
Twitter & 1.94 \\
Instagram & 1.47 \\
LinkedIn & 0.24 \\
\hline Google+ & 1.85 \\
\hline
\end{tabular}

Source: Computed Primary Data Using SPSS 22 Version

Interpretation: Most of the social media users activate in Facebook and Google+. The respondent's activation of social media is identified by ranking social media networks. The study shows that the mean of ranking on Facebook, Twitter, Instagram, LinkedIn, Google+, other social media like Imo, We Chat etc. are respectively 5.95, 1.87, 3.44, 2.27, 4.31, 3.16 and the standard deviations are respectively.254, 1.028, 1.208, 1.061, .828, 1.489. The users on using mostly the Facebook and Google+ in Bangladesh. Most of the social media users have the frequency of Facebook. The study shows that the mean of frequency usage of using Facebook, Twitter, Instagram, LinkedIn, Google+, other social media like Imo, WeChat etc. Are respectively 3.81, .45, 1.47, .24, 1.94, 1.85 and the standard deviations are respectively.598, .977, 1.495, .767, 1.218, 1.453. So, User of Social Media use Facebook more frequently in Bangladesh.

Table 3: Demographic Studies

\begin{tabular}{|l|c|}
\hline \multicolumn{2}{|c|}{ Demographic studies } \\
\hline Respondents' active time in Social media Political Activities & Percentage \\
Never & $22 \%$ \\
1-4 Times & $52.5 \%$ \\
5-9 Times & $18.7 \%$ \\
15-19 Times & $6.8 \%$ \\
\hline Inspiring the respondents to vote in election & $21.7 \%$ \\
Political Campaign on Social Media & $30 \%$ \\
Political Party Leader & $20 \%$ \\
Political Events & $28.3 \%$ \\
Family Politics & $0.00 \%$ \\
Political Rallies & \\
\hline
\end{tabular}

Source: Computed Primary Data Using SPSS 22 Version 
Business Review- A Journal of Business Administration Discipline, Khulna University, Volume: 13, Number: 1E2, January-December 2018, pp.01-12 (Print ISSN : 1811-3788; Online ISSN : 2664-3502)

Interpretation: Study illustrates that people are active in social media about political activities. Only $22 \%$ of the respondents do not spend time on social media for political activities. But 52.5\% respondents are active in 1-4times in a day. The study shows that $30 \%$ inspired by political party leader, $38.3 \%$ by family politics, $20 \%$ by political events and $21.7 \%$ by political campaign on social media to take voting decision. From the opinions, study finds that no respondent is inspired from political rallies. Most of the opinions are in favor of social media inspire respondent to vote in election. Politicians should take social media as an important tool to disseminate message to voters.

Table 4: Descriptive Statistics on Social Media Efficacy and Political Knowledge

\begin{tabular}{|l|c|}
\hline \multicolumn{1}{|c|}{ Descriptive Statistics } & Mean \\
\hline & \\
Social Media Efficacy & 4.07 \\
Social Media enables voters to know their Leader & 3.51 \\
It helps voters to know their Leader's activities \& characteristics & 3.84 \\
It helps leader to promote him to voters quickly & 2.83 \\
\hline It helps the candidate how to cast the voters & 4.10 \\
\hline Voting Right Awareness & 3.72 \\
It helps to know the importance of voting power & 3.47 \\
It helps to know the campaign commitment of every candidate & \\
It influences me to take correct voting decision & 4.03 \\
\hline Respondent's Political Knowledge & 3.17 \\
Voters obtain update political information from social media & 2.91 \\
It helps to increase political knowledge by obtaining updated information & 3.13 \\
Higher political information increases political knowledge from social media & \\
Updated social media information helps to understand the candidate's political activities & 3.49 \\
leaders are judged by voters on the basis of online information & \\
\hline
\end{tabular}

Source: Computed Primary Data Using SPSS 22 Version

Interpretation: The study illustrates that social media helps the voters to know their leaders, their characteristics and their promotion in the election. The study also clarifies that candidates are undecided about all the tools of social media efficacy. The mean opinion states that social media is a helpful way for the voters to know the leaders and for the leaders to promote themselves to voters. The study illustrates that social media helps the voters to know the importance of voting power, the campaign commitment and their decision taking in the election. Social media influence voters to take the correct voting decision by evaluating campaign commitment and the voting power. The social media helps the voters to obtain political information, increase political knowledge, understand the candidate's political activities and their judgment of leaders in the election. The study also clarifies that candidates are undecided about all the tools of political knowledge except voter's judgment based on online information. So, study clarifies that voter are now relying on the social media's information to judge a candidate during the election time.

Table 5: Descriptive Statistics on Social Media and Public Engagement

\begin{tabular}{|l|c|}
\hline \multicolumn{1}{|c|}{ Descriptive Statistics } & Mean \\
\hline & 3.99 \\
Outcome of Social Media & 3.64 \\
It helps the candidate to obtain public trust & 2.90 \\
I can trust on a candidate after knowing his online information & 3.48 \\
Politicians can come close to people by knowing public feedback & 4.42 \\
Online information changes the public's voting behavior & \\
It builds a relationship between political structures and people through online & \\
political campaign & \\
\hline
\end{tabular}


Business Review- A Journal of Business Administration Discipline, Khulna University, Volume: 13, Number: 1E2, January-December 2018, pp.01-12 (Print ISSN : 1811-3788; Online ISSN : 2664-3502)

\begin{tabular}{|l|c|}
\hline Social Consciousness & 3.69 \\
It creates public opinion regarding the politician's good activities & 2.99 \\
It helps the voters to influence on candidate's post-election activities & 3.72 \\
It creates social consciousness about election & 3.06 \\
It helps voters to raise voices against the misdeed of politicians & \\
\hline Open Discussion of Social Media & 4.15 \\
It is an open platform of discussion for the candidate and the voters & 3.84 \\
Voters can share their opinion about political activities on social media & 2.94 \\
Candidate can shape their activities based on public feedback & 3.73 \\
It encourages voters to express their political views & 3.51 \\
It is a place of open public debate & \\
\hline Public Encouragement and engagement & 3.74 \\
It encourages me to vote in the political election & 4.11 \\
It increases voter turnout in the election & 4.21 \\
It engages the youth to participate in the election & 3.80 \\
It encourages public to choose their desired leader & \\
\hline
\end{tabular}

Source: Computed Primary Data Using SPSS 22 Version

Interpretation: The social media helps the candidates to obtain public trust and voters can trust on a candidate by knowing their online information. Social media changes the voters voting behavior and builds a relationship between people and politicians. Study illustrates that candidates are decided on the voter's trust and building relationship, but undecided on changing voting behavior and candidate's closeness to the voter through social media. In case of closeness to voters, politicians cannot come close by knowing public feedback. The social media creates social consciousness regarding creating opinion on politicians' good activities and raises voice against social misdeed. But respondents are quite unconscious about their opinion. But voters think that they can't raise their voice against the misdeed of politicians in social media. The respondents have positive view in the matter that social media as an open discussion platform, social media encourages voters, and voter can share their political opinion. So, social media is a place of discussion and debate for the candidate and voters in election marketing. Social media encourages people to engage in the election to vote and increase voter turnout. The respondents have lower deviation in their opinion, but the respondents have a significant deviation in encouraging voters to vote in elections. So, social media engages the youth to vote and increase voter turnout in elections and helps to choose their desired leader.

Table 6: Descriptive Statistics on Social Media Impact Descriptive Statistics

Social Media impact on communication

It enhances communication between politicians and peoples

It is a landscape for political communication

It helps the candidate to communicate with the unseen people

The candidate can communicate with people through social media live

Voters can communicate between them on their views about election through social media

Candidate can reach to the youth at a short time

\section{Public Trust}

It helps to generate public trust on candidate and election

It helps to generate public trust on voters to vote

It is a reliable tool for candidates view about election

Election Prediction

Social media activity can be a predictor of election result Social media information

influences the election result

It helps to predict about the candidates position in election

Source: Computed Primary Data Using SPSS 22 Version

4.14

3.79

3.83

2.78

3.10

4.00

4.07

3.52

3.23

3.95

3.82

3.54 
Business Review- A Journal of Business Administration Discipline, Khulna University, Volume: 13, Number: 1E2, January-December 2018, pp.01-12 (Print ISSN : 1811-3788; Online ISSN : 2664-3502)

Interpretation: Social media is an effective communication medium between politicians and people. The candidate can reach young people by using social media. The respondents have a lower deviation on that point. But they provide an unconscious view on the point that candidate and voters can communicate through social media options and they have a significant deviation on that argument. So, social media is a platform for political communication for the candidate to communicate with all the actual and potential voters at a time. Social media is a reliable tool for the candidate to generate public trust in election marketing in Bangladesh. This reliable tool helps the voters to trust on the election. The study illustrates the respondents think that social media can be a predictor of election result and social media information influences the election result.

Table 6: Demographic Studies on Social Media Importance and Communication

\begin{tabular}{|l|c|}
\hline \multicolumn{2}{|c|}{ Demographic studies } \\
\hline Social Media Importance for Political Party or Politicians & Percentage \\
$25 \%=$ somewhat unimportant & $5 \%$ \\
$50 \%=$ somewhat important & $21.7 \%$ \\
$75 \%=$ very important & $55 \%$ \\
$100 \%=$ extremely important & $18.3 \%$ \\
\cline { 2 - 2 } Politicians Communication in high forecast area & $2.5 \%$ \\
$0 \%=$ not Possible & $10.8 \%$ \\
$25 \%=$ somewhat Impossible & $40.8 \%$ \\
$50 \%=$ somewhat possible & $42.5 \%$ \\
$75 \%=$ very possible & $3.3 \%$ \\
$100 \%=$ extremely possible & \\
\hline
\end{tabular}

Source: Computed Primary Data Using SPSS 22 Version

Interpretation: Social media is very important for politicians to create interaction between voters and candidates. There is very much possibility for the politicians to reach the high forecast areas voter through social media. It is clear that social media is very much appealing to the politicians to communicate the entire social media user to go to all the voters because the internet and social media user is increasing day by day.

\section{Recommendations \& Conclusion}

Before the most of respondents described that the content, they have read on social media site would have an effect on their action of final voting, further study could investigate why this has transpired, and if these mediums were to be used in future political campaigns to encourage voting, can the response be improved. This review gives a general structure of how an individual's conduct or behavior is influenced by web-based social networking and the level of significance of hardware for them. Henceforth, estimations of cost can be made on the premise of this. Some recommendations of this research are described below:

I. The internet users are increasing continuously. People want to do their work on the internet such as reading newspapers, shopping etc. So, this is a great movement for the politicians to reach to the voters at a short time and encourage them to vote in the election.

II. Social media encourages the users to share their own opinion on Social media networks. So, it is a great opportunity for the politicians to know about the people and their opinions.

III. Young generation is so much fascinated to social media. This is the most effective way for the politicians go to the youth and encourage them to take part in the election.

IV. The study shows that Candidate and voters can exchange their views through social media in real time.

V. The study clears that social media is very important for politicians to come close to the voters. There is a possibility for the politicians to reach voters of high forecast areas through social media. So, it should be a great promotional way to promote the politicians in front of the voters and influence voters to shape their political views.

Younger generation is influenced more on political matters as compared to older generation. Moreover, the survey has indicated that social media was highly successful in engaging the first-time voters in election as these voters are young adults mainly who have recently turned 18 and their usage activity of social media is regular, it would be 
Business Review- A Journal of Business Administration Discipline, Khulna University, Volume: 13, Number: 1E2, January-December 2018, pp.01-12 (Print ISSN : 1811-3788; Online ISSN : 2664-3502)

more accurate to say that they use social media on daily basis. Social networking websites are becoming more and more extensively used as a latest channel for posting, finding and sharing information and content in Bangladesh. This research highlighted that these innovative developments are embraced more by younger generations while older generations are still lagging behind in Bangladesh. Political parties of Bangladesh should focus on social media to do their election marketing.

\section{References}

Ahmed, A. T. (2018), "How Social Media Changes Political Landscape.", Daily Prothom Alo Report, 13 May, pp.2, 3.

Bendor, Y. (2014), “Why social media is so important for your business in 2014”, Retrieved from business2community: http://www.business2community.com/social-media/social-mediaimportant-business2014-0773321.

Bennett, W. L. \& Iyengar, S. (2008), "A new era of minimal effects? The changing foundations of political communication", Journal of Communication, Vol.58 No.4, pp.707-731.

Bernoff, J. \& LI, C. (2008), "Harnessing the power of the oh-so-social web", MIT Sloan Management Review, Vol.49, pp.36.

Claassen, R. L. (2007), "Campaign activism and the spatial model: Getting beyond extremism to explain policy motivated participation"' Political Behavior, Vol.29, pp.369.

Coleman, S. \& Rowe, C. (2005), "Remixing citizenship. Democracy and young people's use of the Internet, Carnegie young people initiative", United Kingdom, UK.

Dale, A. \& Strauss, A. (2009), "Don't forget to vote: Text message reminders as a mobilization tool", American Journal of Political Science, Vol.53 No.4, pp.787-804.

Ellison, N. B. (2007), "Social network sites: Definition, history, and scholarship," Journal of Computer-Mediated Communication, Vol.13 No.1, pp.210-230.

Evans, D. (2010), "Social media marketing: The next generation of business engagement", John Wiley \& Sons, New York, NY.

Fieldhouse, E., Tranmer, M. \& Russell, A. (2007), "Something about young people or something about elections? Electoral participation of young people in Europe: Evidence from a multilevel analysis of the European Social Survey", European Journal of Political Research, Vol.46 No.6, pp.797-822.

Fisher, C. (2007), "Researching and writing a dissertation: A guidebook for business students, Pearson Education", Pearson Education Limited, United Kingdom, UK

Gerodimos, R. (2012), "Online youth civic attitudes and the limits of civic consumerism: The emerging challenge to the Internet's democratic potential," Information, Communication \& Society, Vol.15 No.2, pp.217-245.

Gould, M. (2015), "The social media gospel: Sharing the good news in new ways", Liturgical Press, Minnesota, United States, US.

Gulati, Girish and Williams, Christine B. (2011), Diffusion of Innovations and Online Campaigns: Social Media Adoption in the 2010 U.S. Congressional Election. Retrieved from SSRN: https://ssrn.com/abstract=1925585 or http://dx.doi.org/10.2139/ssrn.1925585 (Accessed May 27, 2019).

Han, G. (2008), "New media use, socio-demographics, and voter turnout in the 2000 presidential election", Mass Communication \& Society, Vol.11 No.1, pp.62-81.

Huang, J., Kornfield, R., Szczypka, G. \& Emery, S. L. (2014), “A cross-sectional examination of marketing of electronic cigarettes on Twitter", Tobacco Control, Vol.23 No.3, pp.26-30.

Jackson, N. \& Lilleker, D. (2011), "Microblogging, constituency service and impression management: UK MPs and the use of Twitter", The Journal of Legislative Studies, Vol.17 No.1, pp.86-105.

Kushin, M. J. \& Yamamoto, M. (2010), "Did social media really matter? College students' use of online media and political decision making in the 2008 election', Mass Communication and Society, Vol.13 No.5, pp.608-630.

Lengel, L., Tomic, A. \& Thurlow, C. (2004), Computer Mediated Communication, Retrieved fromhttps://www.amazon.com/Computer-Mediated-Communication-Crispin-Thurlow/dp/0761949542 (Accessed 26 May 2019).

Loader, B. D. \& Mercea, D. (2012). Social media and democracy: Innovations in participatory politics, Routledge, New York, NY.

Mccarron, R. M., Goroff, D. K., Luhr, J. E., Murphy, M. A. \& Herscowitz, H. B. (1984), "Methods for the collection of peritoneal and alveolar macrophages", Methods in Enzymology, Vol.108, pp.274-284. 
Business Review- A Journal of Business Administration Discipline, Khulna University, Volume: 13, Number: 1E2, January-December 2018, pp.01-12 (Print ISSN : 1811-3788; Online ISSN : 2664-3502)

Nasseri, B. A., Pomerantseva, I., Kaazempur-Mofrad, M. R., Sutherland, F. W., Perry, T., Ochoa, E., Thompson, C. A., Mayer JR, J. E., Oesterle, S. N. \& Vacanti, J. P. (2003). "Dynamic rotational seeding and cell culture system for vascular tube formation”, Tissue Engineering, Vol.9 No.2, pp.291-299.

Panagopoulos, C. (2010), "The dynamics of voter preferences in the 2010 congressional midterm elections", The Forum, Vol.8 No.4, pp.9.

Rainie, L. \& Horrigan, J. (2007). Election 2006 online. Pew Internet \& American Life Project Report, Retrieved from pew research center: https://www.pewinternet.org/2007/01/17/election-2006-online/ (Accessed 26 May 2019).

Rainie, L. \& Smith, A. (2008). Internet and the 2008 Election, Retrieved from pew research center: https://www.pewinternet.org/2008/06/15/the-internet-and-the-2008-election/ (Accessed 26 May 2019).

Ramos, E. (2015), Social Media as a Marketing Tool \& its Impact on Politics Applied Science, Retrieved from: https://www.theseus.fi/bitstream/handle/10024/87648/Ramos_Elisa.pdf?sequence=1\&isAllowed=y (Accessed 26 May 2019).

Sauter, T. \& Bruns, A. (2013), Exploring emotions on\# auspol: polarity, conservativism and public performance in the Twitter debate on Australian politics, In Selected Papers of Internet Research, Association of Internet Researchers, Denver, USA,2013, QUT Eprints, Australia, pp.2-5.

Thompson, N., Permut, R. \& Sutherland, L. (2003), Magazine-Based Data Cartridge Library. Google Patents, Spectra Logic Corp, Colorado, USA, pp.14-22.

Tolbert, C. J. \& Mcneal, R. S. (2003), “Unraveling the effects of the Internet on political participation?" Political Research Quarterly, Vol.56 No.2, pp.175-185.

Tumasjan, A., Sprenger, T. O., Sandner, P. G. \& Welpe, I. M. (2011), "Election forecasts with Twitter: How 140 characters reflect the political landscape”, Social Science Computer Review, Vol.29, pp.402-418.

Ward, J. (2012). Reaching citizens online: how youth organizations are evolving their web presence. In B. D. Loader and D. Mercea (Eds.), Social Media and Democracy: Innovations in Participatory Politics, Routledge, London, pp. 150-165.

Zukin, C., Keeter, S., Andolina, M., Jenkins, K. \& Carpini, M. X. D. (2006), A new engagement? : Political participation, civic life, and the changing American citizen, Oxford University Press. 